\title{
Woman's role as owner/manager in the framework of Albanian business
}

\author{
Shyqyri Llaci / Vasilika Kume
}

Even in the current civilized society, the women have not yet taken heir deserved place. Despite the obvious difficulties in Albania, as well as in the rest of the world, the number of female owners is increasing every day. As their businesses are new, most of them are in the introductory phase of their existance (survival, consolidation and control).

Women as managers are facing several problems related to the lack of resources and inadequate knowledge and skills in management. The difficulties are increased by the fact that they are women.

However, based upon the analysis of the characteristics of a strategic model of management in business owned by woman, we can state that the behaviour of female entrepreneurs is equal to that of male counterparts, but with some characteristics in the management style.

Auch in der heutigen „zivilisierten“ Gesellschaft hat die Frau noch immer nicht den Platz eingenommen den sie verdient. Ungeachtet der offensichtlichen Schwierigkeiten in Albanien, wie auch im Rest der Welt, steigt die Zahl weiblicher Firmeneigentümer täglich. Die Mehrheit von ihnen befindet sich aber noch in der Anfangsphase ihrer wirtschaftlichen Existenz.

Manager sehen sich einer Reihe von Problemen wie Ressourcenknappheit oder einem Mangel an Wissen und Fähigkeiten auf dem Gebiet des Managements gegenüber. Diese Schwierigkeiten treffen weibliche Manager in besonderem Maße.

* Manuscript received: 10.2.97, revised: 22.5.97, accepted: 23.6.97

** Shyqyri Llaci, born 1959, Ass. Prof. Dr., Senior lecturer in "Business organization and management" and Theory of organization and management" in the Department of Management, Faculty of Economics (Tirana University). Major areas of interest: Business management, Organizational change and development, managing change.

Mail address: University of Tirana, Fakulti i Ekonomise, Departmenti i Manaxhimit, Tirana, Albania

Email: Shllaci@economic.tirana.al

Vasilika Kume, born 1955, Dr., Senior lecturer in "Strategic Management" and "Managerial decision-making” in the Department of Management, Faculty of Economics (Tirana University). Major areas of interest: Comparative organizational strategies; management in joint ventures, competitive strategies, managing change. 


\section{Research methodology}

The desire to be the boss, your own boss, and to manage a business of your own is an idea that has tempted many people. This idea has elevated some people to the highest point of fame and success, and crashed some others in the dark abyss of failure. It has to be accepted that business is an enterprise that involves considerable risk, long and hard hours of work, and often very tough sacrifices. For female owners of business, the difficulties and challenges to cope with are probably greater than for the other entrepreneurs, whereas the chances of success are perhaps fewer. Despite the obvious difficulties, as in the rest of the world, the number of the female owners/managers is increasing in Albania.

In this framework, this article aims to achieve some main objectives:

- Through a brief analysis, to describe the social-economic status of women and their struggle for emancipation

- To introduce the basic characteristics of women owned/managed businesses in the context of Albanian business

- To identify the main factors that have had an impact in the level of women's participation and the distinguishing features of management in businesses owned by females

In order to achieve these objectives, the following have been used;

- Interviews with managers/owners of business firms, upon which the questionnaires are based and compiled

- Questionnaires distributed in about 50 women's businesses.

- Statistical data and results provided from the processing of questionnaires

- Conclusions of analysis

\section{I - Background}

The history of mankind since ancient times has shown that all aspects of social, political and economic life are dominated by males, while the female has been treated as a second-class citizen, able to perform only the kind of jobs determined by society under the name and right of the omnipotent owner, the man. Even in current civilized society woman has not yet taken her deserved place, particularly in a practical sense of implementation of the legal framework that already exists.

In this context, Albania is a country, which for the reasons of its history, culture and traditions cultivated through centuries, has suffered more than other European states from the mentality of undervaluing women.

The beginning of this century was promising for Albanian woman. The development of capitalism albeit very slowly, created promise for the 
civilization of our society as a whole, and particularly for women. For the first time they began to go out of their houses to work in the factories and small enterprises, but still few in number and without any special protection by the law.

Several well-educated women who came back from emigration during the 20's 30's, founded the first representative associations. In 1920, in Shkodra, the first magazine of its type was published, entitled: “ The Albanian Woman”. This magazine and others that followed were forced to close down because of the indifference of the state and society as well as the almost total illiteracy of women. Patriarchy in Albania existed in the most cruel form of masculine absolutism until the middle of the century. This patriarchal (and oriental ?) influence isolated the woman from public life.

On the eve of the Second World War according to the statistical data of the time, (excluding peasant women, who were involved in the agricultural sector) only 668 women were working in Albania, and 94 percent of females were illiterate $^{48}$. This situation was worse for those living in the countryside. The "fight" of the progressive elements of that time for an improvement in the situation of women were limited to simple forms of protests and debates. The tradition that began to be created in the 1930s to discuss in the media women's problems not only as humanitarian and dignity issues, but as affairs linked with social development, too, continued in the period of the Liberation Anti- fascist War, where a great number of women fought together with men. For the first time after liberation, women gained the right to vote, and the law stressed equality for employment, payment, social security, education, etc.

After second World War, Albania was the most backward country in Balkan Peninsula, with a very high level of illiteracy (over 80 percent) and the majority of the population working in agriculture. The first economic measures undertaken by the communists in power were to nationalize the few existing factories and trade, and in 1946 they launched the collectivization process. The Party-state presented collectivization as "the only just possible way to edify socialism in the countryside". Hoxha stressed that economic policy should follow Leninist theory, according to which heavy industry constitutes the basis of socialist industrialization.

Up until the mid - 70s, Albania had achieved significant social and economic progress: the high illiteracy rate had been successfully tackled and education was being extended to the whole population. The economy had undergone an effective development process, and national income had more than doubled in the 1960's and 70',s maintaining a high growth rate until 1980. These impressive

48 This very small number of working women was consequence not only of the old mentality, but also of the very limited development of business firms. 
rates of development rates depended mainly on economic support from abroad (financial credit, semi manufactured raw materials, tools, machinery, projects, etc., provided initially from BRSS and then from China).

During these first two decades of the postwar period, the changes in woman's' position in comparison with the past were dramatic as far as employment, education, cultural and social life were concerned. For the first time, it was possible to argue that females were integrated into every aspect of social, economic and political life.

By way of departure from tradition, a sound social opinion was created which encouraged female personalities to make a name for themselves. Across a wide strata of the society, especially for the most progressive, there was engagement in the fight against conservative and patriarchal inheritance, domestic violence and physical mistreatment of woman in general.

In reality, high employment of women in that period was due to economic factors, but also the favourable social policy of the state towards them stimulated this. Job security, remuneration equality, pay for maternity leave, the creation of a health and social services network, increasing number of kindergartens for children firstly in the city and later on in the countryside (despite of their level and quality), the assistance for mothers with many children, were for that time concrete measures that had a positive impact on the position of women.

Later on, especially during the 20 last years of the socialist regime, the political and economical factors that had conditioned woman's development, the growth of her dignity and personality, started to vanish and social action gradually died.

Economic regression was accompanied by the impoverishment of spiritual life. Isolation from the civilized world, lack of information about the world development, propagate darkening of achievements in West, and primarily the thoroughgoing imposition of a ruling ideology and politic caused the restriction of free political, economic and social thought.

The bureaucracy of the whole system incorporated the women's organization, too, which lost its independence in the context of a monopolistic power position of the Party. Its work was reduced in meetings and congresses where political and ideological party problems were dealt with, and specific problems of women and their real concerns neglected.

The absolute state control of economic life, lack of private property even in its small forms, the suffocation of free initiative, the general bureaucracy that occupied the state institutions, high levels of centralization and the pursuit of isolation from the rest of the world (western world) with rigid restriction of foreign trade brought about a deep crisis that covered all aspects of the political, economical and social life. In these conditions, somewhat paradoxically, there 
was nearly total female employment, although the nature of such employment was rendered difficult by the lack of electrical domestic equipment, the existence of a small rations of many food articles, lack of sufficient water, and restricted living space in apartments, etc.

For all the reasons we have mentioned, such as political activism, confidence in their efforts, dissatisfaction towards the regime, very difficult economic conditions, women participated in the movement for a democratic society, based on a market economy.

When transition began, euphoria and illusion gave way to severe reality. Clearly such a transformation can not be done without winners and losers, but the women that entered it with the hope of winning, see themselves as losers in reality. Their interests are being sacrificed for the sake of the transition interests. It was quickly understood that the overflow of products for daily and luxury usage so desired in the past, with the elimination of long queues, etc., could not spontaneously promote an increase in the standard of living level in a sustained way, because of deep inherited poverty. In the cities, mass closure of enterprises, factories, especially those in the light and food industry where women comprised of the largest number of employees, made a large proportion of women workers unemployed. The reconstruction of state administration, closure of some institutions of science, education and culture, and reduction of job places in many other institutions in the shift towards a market economy, first of all touched women who, it must be said, although educated equally to men were attributed an inferior status.

In countryside the situation is different. Private ownership has incited free initiative, increased agricultural production and as a consequence has raised incomes. On the other hand, it is tremendously increased workloass for women, because of male emigration, apart from technical, cultural and psychological factors.

In general, social and political developments have meant that women have emerged to a new position

\section{II - Woman's request for emancipation in today's agenda}

The social and political developments that occurred in our country in the early ' 90 -is, determined a new position for women. The Albanian woman today is trying for an equal participation in social life. This is not a new problem set before us for solution and not even restricted to our country. I is a permanent women's' request in all countries, because despite nationality, women have much in common to be solved. What is different is the time and the priority of issues in the agenda for solution. These are closely linked with the level of social-economic development of a country, traditions and its distinguishing features. We would like to provide an historical dimension also. 
The main reason why the problem for equal treatment is still on the agenda today, despite the progress of human society, is because we still do not know any society where women and men are equal in practice. Even the simple fact that the discussion of sex inequality still goes on, is an indicator of the continuing commitment of society to this very important issue, and that the inequality that really exists is not seen as normal in the modern society of the twentieth century. What is special for Albania is that this question must be again on the agenda as a necessity of the new conditions of our country.

Recently, in the public sector, but in many private firms as well, the hiring of employers through interviews is occurring. This may be viewed as a democratic form that seeks to eliminate inequality and has as it main criteria the ability and professional skills of the candidates. Also, for the first time in Albania, after 50 years, the law sanctions the right to be employed in two jobs in the same time. However, we must admit that the low level of economic development of the country, the slowness of the privatization process, and the lack of creditable institutions for private initiatives, have created difficulties in the real application of employment right for all people and especially for women.

According to the official statistics, the percentage of unemployed women is 24 .1 percent, while for males it is 21 percent. In 1990, the women represented 45 percent of the workforce. This percentage was high, compared with the European average, which for the same year was 35 percent. Actually, about 50 percent of the unemployed are women. In the big cities this figure is 60 percent. Meanwhile of the total number of unemployed women, 65 percent are 35-45 years old (data from the report of NGO's in Albania in 1995).

In this framework, it would be appropriate to instigate a policy with fiscal and economic advantages for those businessmen that invest in new jobs.

NGO's are aiming at this direction through several projects, financed by international and national organisms for new activities where the women's employment is possible. Special attention must be given to the countryside where about 60 percent of the population live and work in a state of economic backwardness.

Despite efforts up to now, it is a fact that the old-fashioned attitude towards women still dominates in Albanian society. Particularly evident is the difference between women in the cities with those living in the countryside, between the women from south and north regions of Albania, between worker and intellectual women. Under these circumstances, if the law recognizes the woman as an equal subject with the man, it is the social mentality that is an obstacle to realize in practice her own rights. Regardless the big changes in the real status of woman in the society, actually she has not taken her deserved place although she represents a great potential not yet exploited properly for the transformation of social-economic life of our country. This idea is reinforced 
even more if we keep in mind that females represent 50.5 percent of our population, and nearly half of the persons with secondary and higher education. ${ }^{49}$

In a questionnaire organized from UNICEF, in 1994 about the conditions of the woman today, taking into account, as well, the changes in the social-economic situation since the Second World War, we can draw some conclusions:

In response to the question: "what was the reason of working?", 39.5 percent answered that this helped the spiritual enrichment and life recognition. Ten percent of the respondents stressed as the main reason for working was to keep the family, 24 percent emphasized the need for independence and for only 4.2 percent of the total - the wish to be equal with the men.

Table 2.1: The reason of working

\begin{tabular}{|l|c|}
\hline The reason of working & Percentage (\%) \\
\hline To keep the family & 10 \\
\hline To be equal with the men & 4.2 \\
\hline To be independent & 24 \\
\hline The work enriches the spiritual life & 39.5 \\
\hline It would be better to stay home & 10.8 \\
\hline I don't know & 11.5 \\
\hline
\end{tabular}

Source: UNICEF-Questionnaire organized in 1994 for Albania

Table 2.2: Areas where the success achieved in the past is in peril?

\begin{tabular}{|l|c|}
\hline $\begin{array}{l}\text { Which are the areas where the } \\
\text { success achieved in the past is in } \\
\text { peril? }\end{array}$ & Percentage \\
\hline Family & 7 \\
\hline Society & 9.3 \\
\hline Politics & 12.8 \\
\hline The three above elements & 6 \\
\hline Is not in a peril & 34 \\
\hline I don't know & 30 \\
\hline
\end{tabular}

Source: UNICEF-Questionnaire organized in 1994 for Albania

49 Source: Statistical Annual of Albania, 1991 
In response to the question: " what was the level of women emancipation and in what period it was achieved?", 10 percent of the interviewers supported the totalitarian regime and 54.2 admitted that it was achieved in the period of democracy. Sixteen percent of the total believed that emancipation is a problem yet unsolved and 18 percent did not answer at all.

Under these circumstances, the question naturally arises: which are the factors that hinder the woman's employment in general, and particularly her employment in important positions in the economic life? Several of these factors are listed as follows:

- The social patriarchal mentality. Despite the fight declared against this mentality over a century ago, it is still evident in our society, and it reappears strongly in its difficult moments. It is displayed in the society, in the family, in the public/private employer and to the woman herself, too.

- The lack of concrete and clear strategies for women's employment and encouragement. Such strategy, has to foresee not only the creation of new working places, but also to include the encouragement and the support for her self-employment. As in some other foreign legislation, in Albania, too, there does not exist yet special laws for woman's defense in the area of employment. This means that perhaps more efforts from the society are needed for eliminating her discrimination by men, and more support for female reintegration in the context of active labor force. It is important to emphasize that her participation in business activities should be encouraged more than has been the case up to now.

- The insufficient resources of institutions for supporting private initiative of small and medium businesses, where women can be involved successfully.

- The lack of training with "the rules of the game" in business. The transformation of woman's ideas in small or medium business, and even in a big business, as well as the creation of her self-confidence for such enterpreneurships. In this direction is the declaration "On the equality between men and women" approved by the Committee of Ministers of European Council, on the 16th, 1988, where we can cite the following:

"The strategies that should be implemented in this area must allow the man and woman to have an equal treatment from legal viewpoint, equal possibilities to use their rights and to develop their own talent. These strategies should foresee, also, suitable measurements, including here special and temporary mechanisms, which aim at the acceleration of a real equality among man and woman”. In this context, it is necessary that the employment, education and qualification of Albanian women should be more stimulated and supported by special laws with temporary application, or to be developed governmental programs in collaboration with non-governmental organizations that would stimulate equal opportunities for women in these areas. 


\section{III - Main characteristics of Albanian business}

In order to be able to judge properly and to draw practicable conclusions for the particularities of owner/manager women in the Albanian conditions, it would be specially interesting to analyze briefly the main characteristics of Albanian business in general.

The deep crisis in which the Albanian economy was involved, burst out in all its components at the beginning of 1990, causing huge unemployment accompanied by ruined industry and agricultural sector. The worse thing was the fact that the country was in depression and this situation seemed to last for a long time. The resolution of these negative consequences would be achieved only through the orientation of our country toward a market economy, whose advantages, particularly in the second half of this century, were displayed in all the areas of social, economic and political life, and especially in the human rights. It was also evident trough the economic development in comparison with the ex-Eastern Block. The archaic legislation of the command economy was substituted in a relatively short time by a new economic structure, which with its base in a very long and successful practic experience of industrialized countries, opened new perspective for the Albanian society as a whole, and for business development in particularly.

Economic reform started in July 1992, when the governmental program was supported by a "stand-by" agreement from IMF. At the core of this reform were three main principles:

Firstly, macroeconomic stabilization that aimed at the reduction of budget deficit, inflation control and the liberalization of prices.

Secondly, the restructuring of state-owned sector that aimed at the elimination of government subsidies, the consolidation of the free competition and the reorganization of public sector and the banking system, as well.

Thirdly, privatization of the economy, including industry, agriculture and public services.

Economic reform undertaken in these three main directions brought about many progressive changes. So, the inflation from 400 percent in 1992, fell to 37 percent in 1993, 16 percent in 1994 and 11percent in 1995. It is to be emphasized that the IMF has evaluated the inflation to be 12percent by the end of 1995. The main reason for price stability has been the stability of "Lek" - the domestic currency, accompanied by the introduction of a tight fiscal and monetary discipline. The unemployment during these years fell to 13 percent in 1995, and according to the statistical data of Ministry of Labor in 1996 it achieved 10.7 percent of the labor force. 
In order to have a more general and understandable picture of the changes that Albanian economy has undergone in a short time, we can look at the figures presented in the table 3.1.

Table 3.1: GDP real growth rate (in percentage)

\begin{tabular}{|l|l|l|l|l|l|l|}
\hline $\begin{array}{l}\text { GDP growth } \\
\text { rate } \\
\text { Sector }\end{array}$ & 1990 & 1991 & 1992 & 1993 & 1994 & 1995 \\
\hline Total GDP & -10.0 & -28.0 & -7.2 & 9.6 & 9.4 & 11.5 \\
Industry & -14.2 & -42.0 & -51.2 & -10.0 & -2.0 & 3.7 \\
Agriculture & -5.4 & -17.4 & 18.5 & 10.4 & 10.3 & 13.0 \\
Construction & -12.0 & -30.0 & 7.0 & 30.0 & 15.0 & 18.8 \\
Transport & -10.0 & -30.0 & -15.0 & 13.0 & 18.0 & 10.0 \\
Other & -8.0 & -14.0 & 9.0 & 16.0 & 11.0 & 9.0 \\
\hline
\end{tabular}

Source: Department of Economic Development and Aid Coordination (In the Council of Ministers)

Foreign aid has been one of the main factors that has ensured the success of economic reform and the transformation of Albanian society during the period of 1992-1995. The orientation and the concentration of this aid have changed according to the phases of economic reform. It has changed gradually from emergency humanitarian aid in technical assistance and macroeconomics support and lastly as an aid for development (mainly investments). ${ }^{50}$ So, the humanitarian aid in 1991 including the food aid represented 85\% of the total, while the support for investment or development projects was zero.

In 1996 the situation was quite different: the humanitarian aid was shifted in aid for investment and development projects representing about 84 percent of the whole aid. The foreign aid is offered by many donors, but the principal donors during these years have been the European Community with 37 percent, Italy with 22 percent, World Bank with 17 percent, Germany with 12 percent and USA with 12 percent. $^{51}$

50 When speaking about economic reform we have in mind the period up to the overall crises which burst out with the collapse of pyramidal firms. This new period needs a special attention which we hope will be presented later on. But for a full analysis it is neccessary to know how Albania was performing generally from 1992-1996. On the other hand, the main objective of this article is the role of woman as owner/ manager in the frame of albanian business in the first five years of transformations.

51 Review: “Ekonomy\&business” Nr 1/1996, p.27. 
Table 3. 2: Foreign aid during 1992-1995 (in million \$)

\begin{tabular}{|l|l|l|l|l|l|}
\hline Year & $\begin{array}{l}\text { Technical } \\
\text { assistance }\end{array}$ & $\begin{array}{l}\text { Development } \\
\text { projects }\end{array}$ & Food aid & Others & Total \\
\hline 1992 & 11.7 & 0 & 139.9 & 52 & 203.6 \\
\hline 1993 & 37 & 17.4 & 71.7 & 107.5 & 233.5 \\
\hline 1994 & 66.4 & 43.9 & 20.7 & 72.5 & 203.6 \\
\hline 1995 & 73.0 & 140.8 & .4 & 73.7 & 287.4 \\
\hline
\end{tabular}

Source: Human Resource Development Report-Albania 1995. Published by UNDP

During the transition period in Albania, there gradually began to flow even foreign capital in the form of direct investments. According to the Albanian Center for Foreign Investment Promotion, the capital invested in Albania in 1996 was 276.1 million \$.

The level of foreign investments in 1995 represented 3.5 percent of GDP of that year. If we take into consideration this indicator Albania can be ranked after Hungary with 10.2 percent, Estonia with 5.8 percent and Czech Republic with 5.6 percent, leaving behind Rumania with 1.0 percent, Bulgaria with 0.8 percent, Slovene with 0.8 percent and Poland with 0.7 percent. The majority of foreign direct investments were concentrated in productive sectors: 34 percent in tourism, 20 percent in light industry, 15 percent in construction, 18 percent in food industry, etc. The orientation of these investments in these sectors is closely linked with natural resources, and the cheap labor, etc. As far as their origin is concerned, it can be said that the main investors were from Western Europe, where Italy comes the first with 50 percent of the total, followed by Greece with 20 percent and Germany with 17 percent, etc. ${ }^{52}$

In Albania like in other Eastern countries, the economic reform was accompanied by many difficulties in the social aspects because of the reduction of many jobs in government administration as well as a result of closing down many inefficient enterprises (with which Albania was "very rich"). An important factor for softening these pains, together with the aid from abroad, has been the incomes from more than 400 thousand Albanian migrants working in foreign countries.

The exodus during '90-'91 is well known, when about 28 percent of the labor force emigrated to Greece (about 80 percent of the total of refugees) and the rest to Italy (which is ranked after Greece in the number of Albanian refugees), Germany and France. The emigrants are an important source of money coming into Albania. According to the approximate evaluations the sum of money from

52 Review “Ekonomy\&business” Nr.1/1996, p.28 
this source is about 400 million $\$$ in a year or nearly $1 / 4$ of the GDP. ${ }^{53}$ Based on these figures we can draw the conclusion that without this aid, the West should have "paid" more for assisting Albania to enter the world of the market economy.

Under these new conditions the first businesses appeared in our country. Characteristic of them was that at the very beginning they were created in trade and service sectors as a result of the privatization, with priority of the retail network which was followed by other sectors of economy, like construction, transport, industry, etc. The successful promotion of SME-s has been the basis of economic reform in the area of private business development. The technical assistance programs and the credit through banking system, SME foundation and regional agencies, business organizations like the Chamber of Commerce as well as other public institutions have supported this process. On the other hand, the rapidly growing number of new businesses and their distribution in many sectors of economy are a very clear reflection of the entrepreneurial spirit of the people engaged in the new world of business that is built according to the rules of another economy: the market economy.

Table 3. 3. The distribution of Albanian businesses according to sectors of economy and their legal status ${ }^{54 .}$

\begin{tabular}{|l|l|l|l|l|l|l|}
\hline Sector & $\begin{array}{l}\text { Physical } \\
\text { persons }\end{array}$ & $\begin{array}{l}\text { Domesti } \\
\text { c firms }\end{array}$ & $\begin{array}{l}\text { Joint } \\
\text { ventures }\end{array}$ & $\begin{array}{l}\text { Foreign } \\
\text { firms }\end{array}$ & Total & In \% \\
\hline Agriculture & 1194 & 283 & 26 & 7 & 1510 & 2.7 \\
\hline Industry & 3255 & 1394 & 292 & 123 & 5064 & 9.0 \\
\hline Construct. & 152 & 961 & 71 & 53 & 1237 & 2.2 \\
\hline Trade & 24762 & 3655 & 1002 & 592 & 30011 & 53.6 \\
\hline Transport & 8654 & 280 & 64 & 48 & 9046 & 16.1 \\
\hline Services & 8551 & 505 & 77 & 67 & 9200 & 16.4 \\
\hline Total & 46568 & 7078 & 1532 & 890 & 56068 & 100.0 \\
\hline
\end{tabular}

If we make some simple comparisons only with a year and a half before, we can see a general growth of the businesses more than 22.5 percent, where we can separate construction businesses with 49 percent (because the construction is an industry with a rapid growth because of the high demand for new constructions and reconstruction in public and private sector.) and the trade businesses with 21 percent (this is normal if we keep in mind that trade is an area of a high

\footnotetext{
53 Albanian Human Development Report-UNDP 1995, p 14.

54 Albanian Human Development Report, UNDP, 1996, p 50.
} 
profit, with relatively small capital and a short rate of return of investments), etc.

In general, Albanian firms have a simple hierarchical structure: at the top is the owner/manager who has one or two assistants - mainly family members or his relatives, and the workers. A main characteristic is the small number of management levels (usually only one level), relationships that are more or less informal, a quick communication with subordinates - which implies relatively quick decision-making, too.

Usually the managerial positions are held by those who have blood relationships with the owner/manager, and as a consequence of this, managerial performance is not evaluated periodically, because it has no any special value for being in managerial positions. Even in those bigger firms, which have a staff of specialists, there does not exist a real and clear line of promotion in the managerial hierarchy.

are flexible, they rarely are expressed in quantitative terms or in a written form.

Table 3.4: SME's distribution for any 100 people ${ }^{55}$

\begin{tabular}{|l|c|}
\hline Some main cities of Albania & SME-s for every 100 people \\
\hline Tirana & 2.9 \\
\hline Fier & 1.5 \\
\hline Korça & 1.9 \\
\hline Elbasan & 1.0 \\
\hline Durrës & 1.9 \\
\hline Shkodër & 1.3 \\
\hline Berat & 1.3 \\
\hline
\end{tabular}

Undoubtedly the principal motive of enterpreneurship in our country has been profit, but we cannot say that this is the only one. The new businesses of Albanians should fulfill several objectives of their proprietors and of their family members - and it is well known that the needs in Albania are greater than in other Eastern Countries. A lot of businesses start with a limited capital and with typical characteristics of family businesses, which have not only to keep their families, but also to fulfill a span of other needs such as for new apartments, life insurance, education, etc. Sometimes, these objectives take on so much importance that the owner/ managers can restrict, even stop at least temporarily, the investments for business expansion. On the other hand, since the objectives of such businesses The majority of businesses are concentrated in

55 Processed by data on “Albanian Human Development Report” 1996, p.9. 
the bigger cities (like Tirana, Shkodra, Korça, Durres, etc.) and in the area of trade and services. The distribution of SME-s for any 100 people is shown in table 3.4.

This situation can be presented in the following graphic:

Figure 3.1: SME's distribution for any 100 people

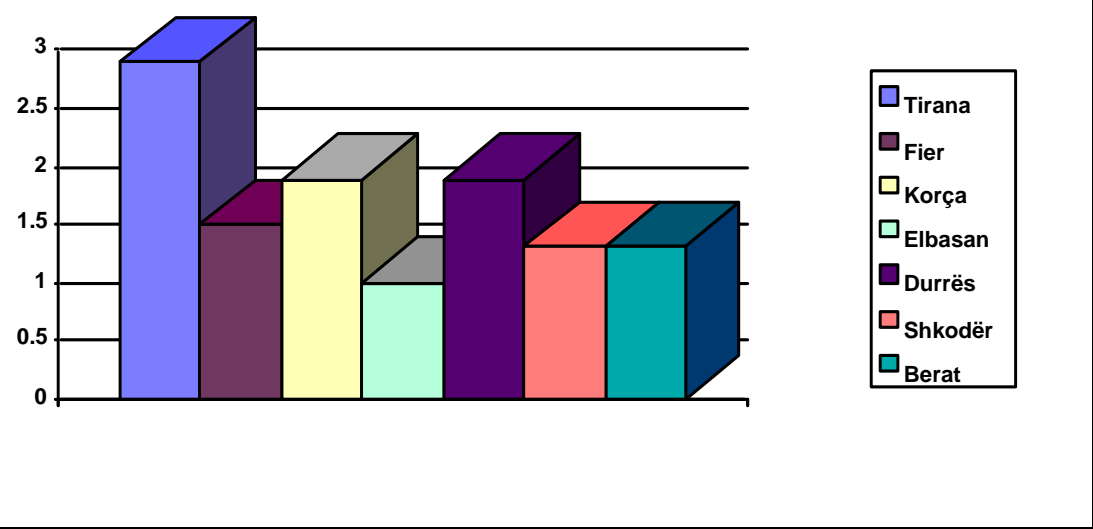

Incomes of individuals working abroad have played a great role along with the support from the banking system and foreign institutions. Also, in this area there are several foreign assistance programs such as the Phare program as well as other projects with German, American and Italian governments. The credits issued by second tier banks with interests ranging from 2-19 percent and one to ten years repayment periods, have greatly stimulated the financial resources of existing and newly started businesses.

The rapid development of new businesses contributes significantly in softening the sharp social problem of unemployment inherited from the past, particularly in the Eastern Countries. According to the data published by EBRD, in the Czech Republic 37 percent of workers are employed in SME-s, in Poland 23 percent, in Rumania 27 percent and in the Slovak Republic 23 percent. In Western European Countries there is an average figure of 69 percent, and in America nearly 53 percent $^{56 .}$ In the Context of more than 56 thousand SME-s in Albania there are employed more than 128 thousand people. If we compared this figure with the year 1992 when the number of employed people was only 60 thousand, we can easily see that for only 3-4 years there has been a growth of more than 200 percent of people employed in the private sector.

The level of qualification of Albanian managers/ owners is still low compared with the requirements of the market economy. The presence of foreign business firms in the Albanian economy has made competition more tough and with international features - hence an intensive training is needed for them. The poor background in this important issue has a negative impact on business success

56 EBRD “Transition report” 1995, p 140. 
and is reflected in the high level of business failure. Now the manager/owner training can be realized through Faculty of Business \& Economics - UT and other specialized institutions like the Institute of Management \& Public Administration and The Banking Training Center.

Considering the main characteristics mentioned above, we can draw some conclusions, the most important of them are listed as follows:

- The geography of Albanian business shows for a disproportional distribution of firms throughout our territory. Clearly there could not be a "proportional development", but despite this, a greater business development in small districts is necessary. The state can play a major role in its stimulation for a more rapid development through a more stimulating legal framework for the businessmen that invest in such areas. Foreign experience shows that the state intervenes with economic mechanisms to encourage the business investment in the relatively less developed areas, as well as to create "economic obstacles" for those wishing to enter super industrialized areas. The free trade zones are potential opportunities yet unexploited for business encouragement to expand in certain areas.

- Bearing in mind the special characteristics of our country in comparison with other Eastern Countries, in the context of our economy the agro-industrial business should be developed and modernized. Economic policy in this direction must continue even more in the further stimulation of this kind of business, because in this area the state with its legislation plays an incentive role.

- The number of businesses in the productive sector still is far from what is possible and the requirements set by the actual stage of development. It was normal that at the first phase of their birth (for many reasons, and above all because of the need for a high profit, the small capital requirements and the high demand for every thing) the businesses would be oriented toward the trade activities. There are a lot of businessmen who actually wish to invest in production, but they still hesitate because of the size of capital they have, the relatively long period of capital return, as well as the high risk and the strong competition especially from foreign companies. The banks and other financial institutions should play a more active role in the process of business credit giving different interest for production and service investments. On the other hand, the pursuit of a protectionist policy for some businesses and products would be an encouraging factor for Albanian investors.

- The danger of failure is a normal phenomenon for those who do not obey in a proper way the rules of the game. Being in the role of referee, the state should take care that all the players are honest and respect fair play. A failure for economic reasons or for the bad management of the firm, but it is undesirable 
to be out of the game from the fiscal evasion of competitors. The state control and the penalties for such cases should be very tough.

- Up to this moment, business firms have asked very rarely for advice and only in the accounting area. Now it is the appropriate time, at least for bigger and stable firms, to ask for expertise with respect to production specialists, marketing and human resources specialists, etc. The competition and the relatively high level of failure because of lack of expertise in management, represent a very strong incentive in the demand for the mature thought of business specialists.

\section{IV - Characteristics of behavior of women as owners}

In this paragraph we wish to identify some of the characteristics of the female behavior as owners. To accomplish this objective, 50 questionnaires were sent to women-owned businesses. Respondents were asked about their personal and business characteristics; their reasons for going into business; the disadvantages and advantages of being a woman business owner; how important income from their business was; and whether their expectations had been met.

\section{Personal characteristics}

Sixty percent of the women entrepreneurs who participated in this study had gone into business on their own initiative. The others had had the encouragement of their husbands or relatives.

Of 50 women entrepreneurs answering the questionnaire, 90 percent were married and only 10 percent were single or divorced.

Forty percent of the respondents had prior experience in their field of endeavor. The majority had not had previous managerial experience.

More than fifty percent of the businesses started by women were 2- 4 years old. Before going into business for themselves they had held a wide variety of jobs in state enterprises. About 64 percent of the respondents have had 4-5 years of business experience. (Table 4.1)

Table 4.1: Prior experience in work and business age of 50 women entrepreneurs.

\begin{tabular}{|l|c|}
\hline & Percentage \\
\hline Prior work experience & \\
\hline Under 5 years & 9 \\
\hline 5 to 10 years & 62 \\
\hline over 10 years & 29 \\
\hline
\end{tabular}




\begin{tabular}{|l|c|}
\hline Years managing your own firm & \\
\hline 4-5 years & 32 \\
\hline 2-4 years & 62 \\
\hline Under 2 years & 6 \\
\hline
\end{tabular}

The educational attainment of the group was above average. Of 50 women entrepreneurs responding, 35 indicated that they had graduate degrees, 10 had done some mini courses in the field where they exercise their activity.(Table 4.2)

Medicine was the most common area of study ( dentist or pharmacist). Very few had studied business. The major part of the respondents had worked as employees in the state administration.(table 4.3)

Table 4.2: Women educational level

\begin{tabular}{|l|c|}
\hline & Percentage \\
\hline Graduate degree & 70 \\
\hline High school & 20 \\
\hline $\begin{array}{l}\text { High school plus a short } \\
\text { specialization }\end{array}$ & 10 \\
\hline
\end{tabular}

Table 4.3: Women profession before going into business

\begin{tabular}{|l|c|}
\hline Profession & Percentage \\
\hline Engineer & 12 \\
\hline Artist, painter & 12 \\
\hline Economist & 13 \\
\hline Seller & 15 \\
\hline Doctor, dentist or pharmacist & 28 \\
\hline Householder & 5 \\
\hline Worker & 13 \\
\hline Student & 2 \\
\hline
\end{tabular}

\section{Nature and Characteristics of Business}

According to "The economist" "Until now, women managers have generally been concentrated in a few areas, especially public administration...Women are also more likely to be managers in fields in which there are lots of women to 
manage: health, say, rather than steel making. That may change as women acquire qualifications in subjects that were once exclusively male". ${ }^{57}$

The majority of the businesses begun by women were service oriented - most commonly retailing. However, the respondents owned many different types of businesses. Included were professional services (pharmacist, dentist) apparel manufacturing, wholesale dealer, designing service, beauty salon etc.(table 4.4)

Some entrepreneurs that operated in non traditional businesses (gathering and manufacturing tobacco, construction etc.), continually felt they had to "prove themselves to be better than male competitors", in order to build and keep clientele.

Of 50 respondents, 64 percent preferred to own their business alone. Twelve percent owned it together with their husbands, 17 percent with foreign partner and only 7 percent with Albanian partner.

Table 4.4: Nature of women businesses

\begin{tabular}{|l|c|}
\hline & Percentage \\
\hline Retailing & 30 \\
\hline Apparel manufacturing & 5 \\
\hline Beauty salon & 25 \\
\hline Wholesale deals & 18 \\
\hline Pharmacist designing and & 8 \\
\hline Dentist & 5 \\
\hline $\begin{array}{l}\text { Advertising, } \\
\text { photographs }\end{array}$ & 5 \\
\hline
\end{tabular}

In general, the majority of the respondents exercised their activity in the locality where they live. Only 15 percent of them had expanded their activity in 4-5 other localities. These were mainly wholesale dealers, gathering and manufacturing tobacco or industrial plants and pharmaceutical products.

In response to the question, "Do you reinvest your business income in your firm, use for informal credit or spend for daily food?", fifty percent of the respondents indicated that they reinvest all the profits. Thirty percent reinvested only a portion of the profit and the remainder gave with interest rate. Twenty percent stated that they lend all the profits.

In response to the question: "Have you technical assistance or consultancy in the management of your business?", the largest part of the respondents (60

57 “The Economist”, August 1996, p.55. 
percent) said "no". About 20 percent pretended to exchange experience with their friends or relatives. The remainder were aware for the need of technical assistance but they had not undertaken any concrete step in this direction.

\section{Reasons for Entry}

"Uncomfortable in a male world, female executives are more likely to move on than their male colleagues. Judith Rosener, of the Irvine school of management at the University of California finds that female executives leave because they feel that they are undervalued, or that they do not fit in. They often move to smaller firms in which the hierarchy seems more permeable, or start their own business. ${ }^{\circ}, 58$.

In a questionnaire organized by UNICEF in 1994, asking for their preferences, 73.6 percent of the respondents would like to work for themselves, 8.2 percent dependent work and 10.2 percent for the state.

Table 4.5: Preferences

\begin{tabular}{|l|c|}
\hline Preference for: & Percentage \\
\hline Working by himself & 73.6 \\
Dependent work & 8.2 \\
Working for the state & 10.2 \\
Don't know & 8 \\
\hline
\end{tabular}

The question: "where is easier for you to find a job", 73.6 percent of the respondents indicated that was easier to find work by oneself.

Table 4.6: Where is easier for you:

\begin{tabular}{|l|c|}
\hline you & Percentage \\
\hline To find work by oneself & 73.6 \\
To find a dependent job & 15.9 \\
don't know & 20.9 \\
\hline
\end{tabular}

The responses of this sample suggest that the motivation of women entrepreneurs is similar to that of their male counterparts. Asked for the reasons of entry in the business, women entrepreneurs have ranked the following reasons.

58 “The Economist”, August 1996, p.55. 
The main reason indicated related to economic conditions. They do not see any other prospect or opportunity to be employed, in conditions when the majority of existing enterprises were shut down as not efficient.

Secondly comes the need to be engaged, to gain personal satisfaction, being one's own boss, the opportunity to make more money, etc. Ten percent of the respondents said that owning a business was the best way for a woman to do the kind of work she preferred, while fifteen said it was the best way for either sex.

Some of the respondents stated that they had gone into business for themselves because of the lack of opportunity for women that they had experienced while working in state organizations. One woman said that she had given fifteen years of her life the work for the state, "doing the work for three men, but getting neither moral nor material promotion”.

Table 4.7: The reason for entering into business

\begin{tabular}{|l|c|}
\hline The entry reasons & Rank \\
\hline Economic conditions & 1 \\
\hline Financial independence & 2 \\
\hline High profit & 3 \\
\hline The need to be involved in work & 4 \\
\hline Personal satisfaction & 6 \\
\hline Desire to be your boss & 7 \\
\hline Career/security & 8 \\
\hline Family responsibility & 9 \\
\hline Time to do something new & \\
\hline
\end{tabular}

\section{Disadvantages and Advantages of Being a Woman}

In a survey organized by IOD, London, most common reasons given for a perceived lack of equal opportunities were:

- Male attitudes towards women (37\%)

- Fewer opportunities for women in senior positions (33\%)

- Difficulties with women returning to work, childcare, flexible working (18\%)

- More difficult for women to prove themselves in the workplace(14\%)

And obstacles to career progression of women:

- Responsibilities to children (35\%)

- Need for career breaks (29\%) 
- Male prejudice (23\%)

- Not been taken seriously (21\%)

- Lack of childcare (16\%)

- Domestic responsibilities (16\%)

(Source: IOD (1992) Members'Opinion Survey: Women's' Participation in the Workforce, London, IOD.)

About forty percent of the respondents of our sample did not think anything would be different if they were men. Thirty percent said that it would be easier to borrow money and 35 percent said it would be easier to deal with the customers

About 75 percent of the entrepreneurs of this group remarked that women are more skilled in dealing with people. They thought that are more flexible, more energetic, independent, competitive, social, self confident and goal oriented. Some others thought that the skills developed in running a household, transfer well to the business world.

All the women entrepreneurs surveyed indicated that they had problems in startup operations. The biggest problem during start-up was lack of financial planning, lack of appropriate education and the need to spend the time for taking care to the family.

What would help these entrepreneurs to overcome their problems? Three things:

1. A support system

2. Further education or qualification

3. Perseverance

The first factor is a strong moral support system of family and friends, clients, business associates and state organisms. Some women entrepreneurs felt that their support system was the key in helping them to overcome problems at startup.

Besides a support system, many women entrepreneurs noted the importance of obtaining an education in business skills. This can be achieved by returning to college, seminars, continuing education courses, conferences, regular reading of trade publications and self help books, as well as help from experts.

While continuing education from a variety of sources is always beneficial, there is no substitute for perseverance, preparation, hard work, and belief in one's product or service. Perhaps the best advice is offered by one entrepreneur: "Be tenacious but realistic; but more important, you have to gamble and take risks. This requires perseverance". 


\section{How Successful Have Been the Businesses Owned by Women?}

Eighty-eight percent of the respondents found running their own business to be either "more profitable" or "about as profitable" as they had expected. Yet, interestingly, 80 percent found that running their own business was only "about as difficult" or "less difficult" than they had expected.

Fifty percent of the respondents said that their businesses provided at least 90 percent of their income. Only 3 percent reported that the business furnished less than 50 percent of their total income. Despite the great engagement of time and energy, the income an entrepreneur provides from his/her business is sometimes more than the income provided by dependent work (5 - 20 times higher)

Table 4.:8 Attitudes of women entrepreneurs toward profitability and difficulty of endeavors.

\begin{tabular}{|l|c|}
\hline Running my own business has been: & Number of responses \\
\hline More profitable than I expected & 29 \\
\hline About as profitable as I expected & 15 \\
\hline Less profitable than I expected & 6 \\
\hline More difficult than I expected & 12 \\
\hline About as difficult as I expected & 28 \\
\hline Less difficult than I expected & 10 \\
\hline
\end{tabular}

\section{Conclusion}

In the light of these problems the entrepreneurs cited, what can be done to make it easier for women entrepreneurs to start and successfully operate new business ventures?

First, women entrepreneurs should gain experience in dealing with money, negotiating, and performing financial responsibilities.

Second, women entrepreneurs should attend seminars and minicourses on finance, marketing and planning. These practical seminars will help entrepreneurs to learn the most recent management techniques while developing skills and confidence.

Third, women entrepreneurs should not hesitate to hire experts, to look for consulting, moral and financial support.

These suggestions will help women entrepreneurs to compensate for weaknesses in their management skills and become more confident and more successful in their endeavours. 


\section{V - Characteristics of Management in women owned businesses}

According to the statistics, the businesses owned by women account for 5 percent of all small businesses in Albania. This indicates an insufficient involvement of women in business. In agriculture, for example, in about 38.000 private farmers, only 50 women have received credits from the Rural Development Fund, in values from 20.000 to 50.000 Leks.

Survival rates in women owned businesses are comparable to those of maleowned ventures. It would be useful, therefore, to gain a better understanding of the factors that explain the success of these ventures.

Previous research suggests that the success of an enterprise is a function of the "fit" among seven strategic elements: shared values, strategies, structures, systems, staff, skills, and styles ${ }^{59}$

To test the configuration of these seven strategic elements seven Albanian businesses owned by women are analyzed. As a first step in this direction, from 50 questionnaires distributed, we selected seven of them. All these businesses operate in Tirana (the capital of Albania) and successfully have outgrown the early start up phase in their respective industries. These cases are summarized in table 5.1 and discussed in more detail in the next part of the paragraph.

Shared values: Three entrepreneurs (owners of a beauty saloon, dentist service and gathering and manufacturing tobacco firm) rated profit much lower than other goals, such as desire to provide a unique service or to fulfill an unaccomplished need of the customers. For the remaining four, however, economic goals such as income, revenue growth and earnings were the prime objectives. The owner of an advertising center is expressed in this way: "One reason I entered into business was because I wanted financial independence in order to do with my life what I wanted". All of these female entrepreneurs expressed the desire to stress the quality of their products or services.

The female entrepreneurs indicated, too, that they wanted to see their firms become the best in their businesses. Of the seven firms studied, the firm of gathering and manufacturing tobacco was at least five times as large as any other, and operated in five districts of Albania and intended to be expanded geographically.

As a key motive for going ahead, its owner envisaged the growth and building of her firm into the best business of its kind. All of those women entrepreneurs display the need for a hard work to make their business successful. The owner of the beauty saloon, the designer center and the gathering \& manufacturing tobacco firm, initially had found difficulty in finding capital.

59 Miles/ Snow (1984), p.1-19. 
Strategies: Customer orientation, finding a market niche and establishing a credible market image appeared to be key marketing strategies for this group of women entrepreneurs. They also emphasized superior customer service and innovative or unique products or services.

The owner of the pharmacy stressed the sophisticated service. She observed: " We offer qualified service. For this I work very closely with my clients and don't laze to serve my clients at home". The owner of designing center felt that her business should offer good design and good response to the client's needs. She stated: " We try to look at what the client wants and help him/her with our expertise".

The financial strategies of the group reflect the fact that in the start-up phase they all had difficulty in procuring capital. This is confirmed by experience cited by other observers of women owned enterprises. Financial problems should be a key factor in the management of the seven businesses taken as a sample. All the women entrepreneurs stated that they preferred a moderate growth. Three of them reinvested only a part of the profit. Two of them reinvested all the profit and only one, the owner of the beauty saloon, stated that she does not reinvest the profits. Apart from the owner of the Gathering \& manufacturing firm who used the credit lines, the other six had not any dealings with banks. They had used for start-up capital their savings or the money gained by emigration.

Structures and systems: As noted in the table 5.1, all the firms have an average growth, and as a result, their structure has remained informal. Three of the entrepreneurs stated that there exist in their firms a mutual confidence and understanding atmosphere. Only the owner of the Gathering \& manufacturing tobacco said that she exercised rigorous supervision over the subordinates. The majority of these firms, however, have remained relatively small, so that the owner continues to maintain simple, but consistent procedures for keeping records of revenue and expenditure. Some observers have found, also, that successful women entrepreneurs are focusing in maintaining close cost control and good planning.

Staff and skills: Some of the respondents stated that they have attended courses related to the fields where they exercised their activity. They declared that they were willing to attend courses in areas such as financial management and business planning, supporting the statement that women entrepreneurs tend to be willing to undergo self-training. All the women, too, regarded the expertise as necessary, but none of them had taken any concrete step. This peculiarity can be explained by the specific conditions in Albania, where there does not exist a real market for this service. These entrepreneurs knew their weaknesses and made efforts to minimize them. 
The great majority of the respondents purported to have a lack of time to attend courses or seminars. Nevertheless, we think that by a better organization of the work and delegation of the responsibilities, they can and must fulfill this duty, in order to do the best for their businesses.

Do women entrepreneurs hire more women employees? Yes, when the firms offer services that are typically provided by women-such as the beauty saloon and the design firms. In other firms, however, the owners stated that they tried to have the right persons for each job, regardless of the sex. Almost all the women stressed the experience and skills of the employees.

Styles: Describing their management styles, nearly all owners confirmed that they motivated their subordinates through wage differentiation and promotion. "We try to work as equals - said one of the owners - If people feel they're respected, they will be productive". Because of the large size of her business, the gathering and manufacturing tobacco firm owner described her style as goaloriented. On the whole, the women entrepreneurs showed a high degree of concern for their employees and preferred to use a delegative style of management. Compared with their male counterparts, female entrepreneurs seem to prefer a more "employee-oriented" and less autocratic management style.

Performance: All entrepreneurs of the group stated that they had an average growth with average profits. They suggested that they had a good reputation. Conservatism with regard to both financial management and growth perspective were characteristics of the female entrepreneurs. The majority liked high profits and growth, however, they remain small. 
Table 15: Background and management style in 7 women enterprises

\begin{tabular}{|l|l|l|l|l|l|l|l|}
\hline Business type & Retailing & $\begin{array}{l}\text { Textile } \\
\text { production }\end{array}$ & Beauty salon & Pharmacy & $\begin{array}{l}\text { Dentist } \\
\text { service }\end{array}$ & $\begin{array}{l}\text { Tobacco } \\
\text { Gathering } \\
\text { Processing }\end{array}$ & $\begin{array}{l}\text { Graphic } \\
\text { center } \\
\text { (Advertising) }\end{array}$ \\
\hline Age (years) & 5 & 4 & 2 & 4 & 3 & 4 & 2 \\
\hline $\begin{array}{l}\text { Previous } \\
\text { experience }\end{array}$ & Architect & $\begin{array}{l}\text { Textile } \\
\text { engineer }\end{array}$ & $\begin{array}{l}\text { Literature } \\
\text { critic }\end{array}$ & Pharmacist & Dentist & Student & Painter \\
\hline $\begin{array}{l}\text { Reasons of } \\
\text { staring-up }\end{array}$ & $\begin{array}{l}\text { Economic } \\
\text { conditions }\end{array}$ & $\begin{array}{l}\text { Need of } \\
\text { getting } \\
\text { involved in a } \\
\text { job }\end{array}$ & $\begin{array}{l}\text { Personal } \\
\text { satisfaction, } \\
\text { Economic } \\
\text { conditions }\end{array}$ & $\begin{array}{l}\text { Economic } \\
\text { conditions, } \\
\text { high profits }\end{array}$ & $\begin{array}{l}\text { Financial } \\
\text { independence } \\
\text { high profits }\end{array}$ & $\begin{array}{l}\text { Financial } \\
\text { independence } \\
\text {, high profits }\end{array}$ & $\begin{array}{l}\text { Economic } \\
\text { conditions, } \\
\text { desire to } \\
\text { work in an } \\
\text { unexplored } \\
\text { field before }\end{array}$ \\
\hline $\begin{array}{l}\text { Values they } \\
\text { want to } \\
\text { achieve }\end{array}$ & $\begin{array}{l}\text { Revenue } \\
\text { increase, } \\
\text { Profits }\end{array}$ & $\begin{array}{l}\text { Profits and } \\
\text { satisfaction of } \\
\text { unsatisfied } \\
\text { customer } \\
\text { needs }\end{array}$ & $\begin{array}{l}\text { Satisfaction } \\
\text { of unsatisfied } \\
\text { customer } \\
\text { needs, } \\
\text { revenue } \\
\text { increase }\end{array}$ & $\begin{array}{l}\text { Profits, } \\
\text { revenue } \\
\text { increase, } \\
\text { financial } \\
\text { independence }\end{array}$ & $\begin{array}{l}\text { linique } \\
\text { service, } \\
\text { revenue } \\
\text { increase }\end{array}$ & $\begin{array}{l}\text { Unique } \\
\text { service, } \\
\text { revenue } \\
\text { increase }\end{array}$ & $\begin{array}{l}\text { Creation of a } \\
\text { unique } \\
\text { service, } \\
\text { profits }\end{array}$ \\
\hline
\end{tabular}




\begin{tabular}{|c|c|c|c|c|c|c|c|}
\hline $\begin{array}{l}\text { Strategies, } \\
\text { structures, } \\
\text { systems }\end{array}$ & $\begin{array}{l}\text { To satisfy } \\
\text { costumer } \\
\text { wants, to } \\
\text { create } \\
\text { customer } \\
\text { loyalty, } \\
\text { Expenditure } \\
\text { control, cost } \\
\text { reduction, } \\
\text { reinvesting } \\
\text { profits }\end{array}$ & $\begin{array}{l}\text { Customer } \\
\text { orientation, } \\
\text { reliable } \\
\text { market, high } \\
\text { quality } \\
\text { products, } \\
\text { financial } \\
\text { expenditure } \\
\text { control, } \\
\text { reinvesting } \\
\text { profit. }\end{array}$ & \begin{tabular}{|l|} 
Customer \\
orientation, \\
high quality \\
service, self \\
financing, \\
sound control \\
on \\
expenditure \\
non \\
reinvesting \\
profits, no \\
contracts with \\
banks
\end{tabular} & $\begin{array}{l}\text { Very polite } \\
\text { service, at } \\
\text { home service, } \\
\text { advert use, } \\
\text { rigid control } \\
\text { on services, } \\
\text { partly } \\
\text { reinvesting } \\
\text { profits, no } \\
\text { contracts with } \\
\text { banks. }\end{array}$ & \begin{tabular}{|l|} 
Customer \\
orientation, \\
funds of \\
starting-up \\
the businesses \\
come from \\
savings, \\
control on \\
financial \\
expenditure, \\
partly \\
reinvesting \\
profits.
\end{tabular} & $\begin{array}{l}\text { Securing a } \\
\text { center } \\
\text { market, high } \\
\text { quality } \\
\text { products. } \\
\text { Control on } \\
\text { expenditure } \\
\text { through } \\
\text { norms, usage } \\
\text { of bank loan, } \\
\text { reinvesting } \\
\text { profits. }\end{array}$ & $\begin{array}{l}\text { Satisfying } \\
\text { customer } \\
\text { wants on time } \\
\text { and in a high } \\
\text { quality. } \\
\text { Usage of } \\
\text { loans, control } \\
\text { on } \\
\text { expenditure, } \\
\text { partly } \\
\text { reinvesting } \\
\text { profits. }\end{array}$ \\
\hline Performance & $\begin{array}{l}\text { Average } \\
\text { growth, 10\% } \\
\text { per aunnum. } \\
\text { Medium } \\
\text { profits, good } \\
\text { reputation. }\end{array}$ & $\begin{array}{l}\text { Medium } \\
\text { growth, } \\
\text { medium } \\
\text { profits, good } \\
\text { reputation }\end{array}$ & $\begin{array}{l}\text { Medium } \\
\text { growth, } \\
\text { medium } \\
\text { profits, very } \\
\text { good } \\
\text { reputation }\end{array}$ & $\begin{array}{l}\text { Medium } \\
\text { growth, } \\
\text { medium } \\
\text { profits, good } \\
\text { reputation }\end{array}$ & $\begin{array}{l}\text { Medium } \\
\text { growth, } \\
\text { medium } \\
\text { profits, good } \\
\text { reputation }\end{array}$ & $\begin{array}{l}\text { Medium } \\
\text { growth, } \\
\text { medium } \\
\text { profits, very } \\
\text { good } \\
\text { reputation }\end{array}$ & $\begin{array}{l}\text { Medium } \\
\text { growth, } \\
\text { medium } \\
\text { profits, good } \\
\text { reputation }\end{array}$ \\
\hline
\end{tabular}




\begin{tabular}{|c|c|c|c|c|c|c|c|}
\hline \begin{tabular}{|lr} 
Staff $\quad \&$ \\
management \\
style
\end{tabular} & $\begin{array}{l}\text { Trusty } \\
\text { environment } \\
\text { in the firm. } \\
\text { Staff } \\
\text { employed by } \\
\text { criteria of } \\
\text { experience } \\
\text { and age. } \\
\text { Enforcing } \\
\text { employee } \\
\text { motivation } \\
\text { through } \\
\text { supple- } \\
\text { mentary } \\
\text { remuneration } \\
\text { and status } \\
\text { from } \\
\text { employees. } \\
\text { Reliability } \\
\text { and respect to } \\
\text { customers. }\end{array}$ & $\begin{array}{l}\text { Rigid } \\
\text { supervision } \\
\text { on } \\
\text { subordinates, } \\
\text { staff } \\
\text { employed by } \\
\text { criteria of } \\
\text { experience } \\
\text { and age. } \\
\text { Motivation } \\
\text { through wage } \\
\text { differentiatio } \\
\text { n and supple- } \\
\text { mentary } \\
\text { remuneration. } \\
\text { Demanding } \\
\text { from } \\
\text { employees } \\
\text { high quality } \\
\text { jobs and duty } \\
\text { accomplish- } \\
\text { ment. }\end{array}$ & $\begin{array}{l}\text { Trusty } \\
\text { environment } \\
\text { in the firm. } \\
\text { Staff } \\
\text { employed by } \\
\text { the criteria of } \\
\text { experience. } \\
\text { Demanding } \\
\text { from } \\
\text { employees a } \\
\text { high quality } \\
\text { job and } \\
\text { customer } \\
\text { respect. } \\
\text { Motivation } \\
\text { through wage } \\
\text { differentiatio } \\
\text { n and } \\
\text { increased } \\
\text { responsibility }\end{array}$ & $\begin{array}{l}\text { Trusty } \\
\text { environment } \\
\text { in the firm. } \\
\text { Staff } \\
\text { employed by } \\
\text { the criteria of } \\
\text { education and } \\
\text { experience. } \\
\text { Demanding } \\
\text { from the } \\
\text { employees a } \\
\text { high quality } \\
\text { job and } \\
\text { customer } \\
\text { respect. } \\
\text { Motivation } \\
\text { through wage } \\
\text { differentiatio } \\
\text { n and } \\
\text { increased } \\
\text { responsibility. }\end{array}$ & $\begin{array}{l}\text { There is not } \\
\text { authority } \\
\text { delegation. } \\
\text { Main criteria } \\
\text { of } \\
\text { employment } \\
\text { are gender } \\
\text { and } \\
\text { education. } \\
\text { Motivation } \\
\text { through wage } \\
\text { differentiatio } \\
\text { n and supple- } \\
\text { mentary } \\
\text { remuneration. } \\
\text { Demanding } \\
\text { from } \\
\text { employees } \\
\text { high quality } \\
\text { job and } \\
\text { customer } \\
\text { respect. }\end{array}$ & $\begin{array}{l}\text { Rigid } \\
\text { supervision } \\
\text { on } \\
\text { subordinates. } \\
\text { Staff } \\
\text { employed by } \\
\text { criteria of } \\
\text { experience } \\
\text { and specialty. } \\
\text { Motivation } \\
\text { through } \\
\text { increased } \\
\text { responsibility } \\
\text { and wage } \\
\text { differentiatio } \\
\text { nDemanding } \\
\text { from } \\
\text { employees } \\
\text { loyalty and } \\
\text { high quality } \\
\text { job. }\end{array}$ & $\begin{array}{l}\text { Trusty } \\
\text { environment } \\
\text { in the firm. } \\
\text { Authority } \\
\text { delegation. } \\
\text { Staff } \\
\text { employed by } \\
\text { criteria of } \\
\text { experience } \\
\text { and specialty. } \\
\text { Motivation } \\
\text { through } \\
\text { supple- } \\
\text { mentary } \\
\text { remuneration } \\
\text { and wage } \\
\text { differentiatio } \\
\text { nDemanding } \\
\text { from } \\
\text { employees } \\
\text { high quality } \\
\text { job and } \\
\text { customer } \\
\text { respect. }\end{array}$ \\
\hline
\end{tabular}




\section{Conclusion}

In summary, we do not pretend to represent the behavior of all female entrepreneurs in Albania by a sample of seven firms. However, based on the above analysis we can state that the behavior of female entrepreneurs is equal with that of male counterparts, but with some specifics in the management style, which appears to be more "feminine".

\section{References}

Bartol, K./ Martin, D. (1994): Management, Mc Graw-Hill, pp 658-681.

Boon, E./ Kurtz, D. (1993): Contemporary Business, Dryden Press, USA, pp 174-191, 531539.

Chaganti, R. (1986): Management in women-owned enterprises, in: Journal of Small Business, October, pp 18-28.

EBRD (1995): Transition Report, London, pp 140-141.

Kai, B. (1996): The violence against women-a national concern (Dhuna kunder grave nje problem kombetar), Dora D’Istra Press Tirana, pp 5-22.

Kargac, J./ Parnell, J.A. (1996): Strategic Planning Emphasis and Planning Satisfaction in Small Firms, in: Journal of Business Strategies, Texas, Nr. 1, pp 3-18.

Kinard, J. (1988): Management, Heath and company, Toronto, pp 531-537.

Meaj, V. (1996):The women legal rights and their defense in employment relations (te drejtat ligjore te grave dhe mbrojtja e tyre ne marredheniet e punesimit), Dora D'Istra Press Tirana, pp 7-12.

Miles, R.E./ Snow, C.C. (1984): Strategy and Organization-Pitman Publishing and California Management Review, p.1-19.

Perlaki, I. (1993): Management Development for Eastern Europe, in: Multinational Business Review, Nr. 1, pp 10-15.

Pino, S. (1995): Woman request for equal citizenship in the agenda (Kerkesa e gruas per qytetari te barabarte ne rend te dites), Dora D’Istra Press Tirana, pp12-15.

Porter, M. (1991): Towards a Dynamic Theory of Strategy, in: Strategic Management Journal, pp 95-110.

UNDP (1996): Albanian Human Development Report, Tirana, pp 30-50. 